\title{
CONTEXTUAL TEACHING AND LEARNING UNTUK MENINGKATKAN KEMAMPUAN PEMAHAMAN KONSEP PECAHAN
}

\author{
Rina Indriani ${ }^{1}$, Ari Metalin Ika Puspita ${ }^{2}$, Mimin Ninawati ${ }^{3}$, Hany Handayani ${ }^{4}$, Agusfianuddin $^{5}$ \\ ${ }^{1}$ Universitas Pasundan \\ rinaindriani@unpas.ac.id \\ ${ }^{2}$ STKIP PGRI Trenggalek \\ arimetalinikapuspita@stkiptrenggalek.ac.id \\ ${ }^{3}$ Universitas Muhammadiyah Prof. Dr. HAMKA \\ nina.adenasution@yahoo.com \\ ${ }^{4}$ STKIP Purwakarta \\ jejakcerita@yahoo.com \\ ${ }^{5}$ IKIP Mataram \\ agusfianuddin@gmail.com
}

\begin{abstract}
ABSTRAK
Salah satu kemampuan dasar dalam mempelajari matematika adalah kemampuan siswa dalam memahami matematika. Kemampuan pemahaman matematis akan mengembangkan kemampuan matematis yang lainnya, diantaranya kemampuan komunikasi, koneksi, dan pemecahan masalah. Untuk dapat mengasah kemampuan matematis siswa, diperlukan suatu model pembelajaran yang sesuai dengan karakter siswa dan materi yang diajarkan. Salah satu model pembelajaran yang dapat meningkatkan hasil belajar siswa adalah model Contextual Teaching and Learning (CTL). Metode yang digunakan dalam penelitian ini yaitu Penelitian Tindakan Kelas (PTK). Subjek dalam penelitian ini adalah siswa kelas V Sekolah Dasar. Instrumen yang digunakan dalam penelitian ini adalah tes dan lembar observasi aktivitas guru dan siswa. Berdasarkan analisis data hasil penelitian, diperoleh kesimpulan bahwa CTL dapat meningkatkan kemampuan pemahaman matematis konsep pecahan siswa SD. Dengan demikian penggunaan model pembelajaran CTL dapat dijadikan sebagai salah satu alternatif pembelajaran untuk diterapkan pada pembelajaran matematika di SD, khususnya dalam mempelajari konsep pecahan.
\end{abstract}

Kata Kunci: Contextual Teaching and Learning, Pemahaman Matematis, Pecahan.

\begin{abstract}
One of the basic abilities in learning mathematics is the ability of students to understand mathematics. Mathematical comprehension ability will develop other mathematical abilities, including communication, connection and problem-solving abilities. To be able to hone students 'mathematical abilities, a learning model is needed that is appropriate to the students' character and the material being taught. One learning model that can improve student learning outcomes is the Contextual Teaching and Learning (CTL) model. The method used in this study is Classroom Action Research (CAR). Subjects in this study were fifth grade in Elementary School. The instruments used in this study were tests and observation sheets of teacher and student activities. Based on the analysis of research data, it is concluded that CTL can improve the ability of mathematical understanding of fraction concept for elementary
\end{abstract}


students. Thus, the use of CTL learning models can be used as an alternative learning to be applied to learning mathematics in elementary school especially on learning concept of fractions.

Keywords: Contextual Teaching and Learning, Mathematical Understanding, Fraction.

Format Sitasi: Indriani, R., Puspita, A. M. I., Ninawati, M., Handayani, H., \& Agusfianuddin. (2019). Contextual Teaching and Learning untuk Meningkatkan Kemampuan Pemahaman Konsep Pecahan. KALAMATIKA Jurnal Pendidikan Matematika, 4(1), 109-116.

Penyerahan Naskah: 16 Maret 2019 || Revisi: 2 Mei 2019 || Diterima: 3 Mei 2019

\section{PENDAHULUAN}

Matematika merupakan ilmu pengetahuan yang banyak digunakan dalam ilmu pengeahuan lain maupun kehidupan sehari-hari. Disadari atau tidak, manusia tidak bisa menghindari matematika, karena dalam kehidupan sehari-hari seringkali dihadapkan pada permasalahan-permasalahan matematika. Oleh sebab itu, matematika sangat penting untuk dipelajari.

Kemampuan awal yang diperlukan dalam matematika adalah kemampuan memahami matematika. Kemampuan pemahaman ini perlu diasah agar dapat mengembangkan kemampuan matematika yang lainnya, seperti kemampuan komunikasi, pemecahan masalah, koneksi, berpikir kritis dan lainnya.

Untuk mengasah kemampuan matematis siswa, guru hendaknya dapat menciptakan pembelajaran yang mengarahkan siswa untuk belajar aktif serta mengembangkan pengetahuan yang dimilikinya. Selain itu, siswa juga dapat mengkonstruksi pengetahuan mereka melalui pembelajaran yang mereka lakukan.

Materi pecahan dianggap sebagai salah satu materi yang sulit dalam pembelajaran matematika yang mengakibatkan kurangnya pemahaman siswa pada konsep pecahan di kelas IV SDN Singawada II. Padahal dalam kehidupan sehari-hari, konsep pecahan ini banyak digunakan.

Salah satu yang bisa dilakukan guru dalam mengasah kemampuan pemahaman matematis siswa, khususnya siswa sekolah dasar, adalah dengan memilih metode pembelajaran yang sesuai dengan keadaan siswa dan materi yang diajarkan.

Berdasarkan hasil observasi di lapangan, yaitu di SD Negeri Singawada II, pada pelajaran matematika cenderung berpusat pada guru, seta pembelajaran disajikan secara verbal, 
dengan keterlibatan siswa yang sangat minim karena siswa hanya melakukan kegiatan duduk, diam, mendengar, mencatat, dan menghapal.

Salah satu metode pembelajaran yang dianggap dapat menjadi solusi dari permasalahan diatas adalah dengan menggunakan Contextual Teaching and Learning (CTL). Metode pembelajaran CTL ini menerapkan pembelajaran yang langsung dikaitkan dengan kehidupan sehari-hari, agar siswa lebih mudah memahami materi yang diajaran, karena berhubungan langsung dengan lingkungan hidup mereka. Selain itu, siswa diharapkan memiliki keterampilan menghubungkan matematika dengan kehidupan sehari-hari dan menerapkannya dalam soalsoal. Melalui pembelajaran ini juga, siswa dihadapkan pada masalah kontekstual yang mengantar siswa mengenal objek matematika, melibatkan siswa melakukan proses matematika secara aktif.

Bloom (dalam Anderson \& David, 2010) mengklarifikasikan pemahaman ke dalam jenjang kognitif kedua yang menggambarkan suatu pengertian, sehingga seseorang mengetahui bagaimana berkomunikasi dan mengemukakan idenya untuk berkomunikasi. Dalam pemahaman tidak hanya sekedar memahami sebuah informasi tetapi termasuk juga keobjektifan, sikap dan makna yang terkandung dari sebuah informasi. Dengan kata lain seseorang dapat mengubah suatu informasi yang ada dalam pikirannya kedalam bentuk lain yang lebih berarti.

Pemahaman matematis merupakan landasan penting untuk berpikir dalam menyelesaikan persoalan-persoalan matematika maupun persoalan-persoalan di kehidupan sehari-hari. Mengembangkan kemampuan pemahaman matematis merupakan salah satu tujuan dalam kurikulum, kemampuan tersebut sangat mendukung pada kemampuan-kemampuan matematis yang lain, yaitu komunikasi, penalaran, koneksi, representasi, dan problem solving.

Menurut Johnson (2008), "CTL adalah sebuah sistem yang menyeluruh. CTL terdiri dari bagian- bagian yang saling terhubung. Jika bagian-bagian ini terjalin satu sama lain, maka akan dihasilkan pengaruh yang melebihi hasil yang diberikan bagian-bagiannya secara terpisah. Setiap bagian CTL yang berbeda-beda ini memberikan sumbangan dalam menolong siswa memahami tugas sekolah. Secara bersama-sama mereka mereka membentuk suatu sistem yang memungkinkan para siswa melihat makna di dalamnya, dan mengingat materi”. Pendekatan Kontekstual merupakan suatu pendekatan yang mampu memngembangkan suatu pembelajaran yang bermakna. 
Menurut Puspita (2016) Peningkatan yang dilihat ketika siswa menggunakan buku teks berbasis kontekstual, meliputi (1) kedisiplinan siswa mengikuti pembelajaran, (2) ketelitian dalam melaksanakan tugas, (3) kemandirian dalam mengerjakan evaluasi, (4) tanggung jawab untuk menyelesaikan tugas, (5) ketepatan waktu dalam mengumpulkan tugas, (6) keaktifan dalam proses pembelajaran, dan (7) meningkatkan hasil belajar siswa dalam menggunakan produk buku teks berbasis kontekstual. Sedangkan Puspita (2018) menyatakan bahwa pendekatan kontekstual merupakan pendekatan yang melibatkan pengalaman individu untuk mendapatkan pengetahuan baru, berbagi informasi, serta aplikasi pengetahuan di dalam kehidupan. Sehingga Pendekatan Kontekstual yang dirancang sesuai karakteristik dan lingkungan belajar siswa dapat menumbuhkan sikap positif siswa di dalam proses pembelajaran.

Dari penjelasan di atas, penelitian ini diarahkan untuk melihat pengaruh penggunaan model pembelajaran CTL berdasarkan peningkatan yang terjadi pada pemahaman matematis siswa pada konsep pecahan.

\section{METODE PENELITIAN}

Metode yang digunakan dalam penelitian ini adalah dengan pendekatan penelitian kelas (classroom action research) atau sering disingkat PTK, yang merupakan salah satu bentuk penelitian tindakan. Penelitian tindakan merupakan penelitian dengan menerapkan pembelajaran yang sistematis dengan tujuan untuk meningkatkan praktik pendidikan dengan tindakan dalam praktik dan refleksi mempengaruhi tindakan yang dilakukan (Iskandar \& Narsim, 2015).

PTK merupakan salah satu bentuk penelitian yang bersifat tindakan-tindakan tertentu untuk memperbaiki dan meningkatkan praktik-praktik pembelajaran di kelas. Dalam PTK, penelitian berfokus pada pengembangan pendidikan dalam skala mikro, atau berfokus pada aktivitas pembelajaran di dalam kelas.

Selain pengertian di atas, penelitian tindakan kelas dapat dikatakan juga sebagai sarana untuk penilaian proses pembelajaran, dan bahkan proses pendidikan dalam skala makro. Hasil penelitian ini akan memberikan masukan yang bermanfaat untuk memperbaiki praktek pembelajaran di kelas, sehingga proses pembelajaran menuju ke arah yang lebih profesional. Penelitian tindakan kelas dapat dilakukan oleh setiap guru untuk meningkatkan kualitas pembelajaran tanpa meninggalkan tugas utama sebagai pengajar. Penelitian tiandakan kelas harus dilakukan secara logis, sistematis, serta jujur dalam laporan, sehingga akan diperoleh data 
yang valid sesuai dengan fakta di lapangan. Data yang diperoleh dapat dijadikan acuan untuk memperbaiki dan meningkatkan efektifitas pembelajaran.

Tujuan dilakukannya penelitian ini adalah untuk melihat peningkatan dan pengaruh penggunaan model CTL pada kelas IV SDN Singawada II pada materi pecahan. Hal tersebut sejalan dengan pendapat Subyantoro (dalam Iskandar \& Narsim, 2015) yang menyebutkan bahwa penelitian tindakan ini bertujuan praksis pembelajaran sehingga guru dapat mengembangkan proses belajar mengajar di kelas.

\section{HASIL DAN PEMBAHASAN}

Seperti yang sudah di bahas pada hasil penelitian dari mulai siklus I dan II siswa mengalami perubahan dan peningkatan hasil belajar, baik itu pada pre-test, LKS maupun posttest, sebagai berikut:

1. Pada siklus I, dari 28 orang siswa yang hadir pada pre-test siswa yang belum tuntas 16 orang dan yang sudah tuntas 12 orang, pada post-test siswa yang belum tuntas 11 orang dan yang sudah tuntas 17 orang, sedangkan dalam Lembar Kerja Siswa 1 kelompok belum mencapai KKM dan 4 kelompok lainnya sudah mencapai KKM, atau tingkat keberhasilannya hanya $80 \%$.

2. Pada siklus II, dari 28 siswa pada pre-test yang belum tuntas yaitu 8 orang dan yang sudah tuntas 20 orang, pada post-test siswa yang belum tuntas yaitu 3 orang dan yang sudah tuntas 25 orang, dan dalam Lembar Kerja Siswa meraih persentase keberhasilan 100\%, seluruh kelompok sudah mencapai nilai KKM.

3. Pada siklus III, dari 28 siswa pada pre-test yang belum tuntas yaitu 8 orang dan yang sudah tuntas 20 orang, pada post-test siswa tuntas 28 orang, dan dalam Lembar Kerja Siswa meraih persentase keberhasilan 100\%, seluruh kelompok sudah mencapai nilai KKM.

Berdasarkan hasil penelitian di atas, maka diketahui bahwa penggunaan model CTL pada materi pecahan dapat mengingkatkan pemahaman konsep pecahan siswa. Siswa yang memperoleh pembelajaran matematika dengan Contextual Teaching and Learning dibiasakan untuk mengemukakan pendapat dan alasan-alasan yang mendukung pendapatnya yang tentunya memerlukan pemahaman yang baik. Sehingga, dalam pengerjaan soal-soal yang diberikan siswa sudah terbiasa dengan soal-soal yang menuntut mereka mengemukakan pendapat dan alasanalasan dari jawaban mereka. 
Pengajaran matematika mempunyai tujuan yang sangat luas, salah satu tujuannya adalah agar siswa memiliki keterampilan menghubungkan matematika dengan kehidupan sehari-hari dan menerapkannya dalam soal-soal. Dengan demikian penerapan model Contextual Teaching and Learning (CTL) dalam pembelajaran matematika melibatkan siswa untuk dapat berperan aktif dengan bimbingan guru, agar peningkatan kemampuan siswa dalam memahami konsep dapat terarah lebih baik.

The Northwest Regional Education aboratory USA (Manshur, 2011) mengidentifikasi adanya 6 kunci dasar yang menentukan kualitas dari Contextual Teaching and Learning (CTL), yakni: pembelajaran bermakna, penerapan pengetahuan, berpikir tingkat tinggi, kurikulum yang dikembangkan berdasarkan kepada standar, responsi terhadap budaya, dan penilaian autentik.

\section{KESIMPULAN}

Berdasarkan hasil penelitian yang dilakukan oleh peneliti, dapat disimpulkan bahwa penggunaan model pembelajaran CTL pada pembelajaran materi pecahan dapat mengingkatkan pemahaman konsep pecahan siswa. Dengan kata lain model pembelajaran CTL dapat dijadikan salah satu solusi untuk mengembangkan kemampuan pemahaman matematis siswa sekolah dasar khususnya pada materi pecahan.

\section{REKOMENDASI}

Penelitian ini merupakan jenis penelitian Penelitian Tindakan Kelas (PTK) yang bertujuan untuk meningkatkan kemampuan matematis siswa sekolah dasar. Pengembangan suatu produk baik itu berupa bahan ajar, metode, atau model pembelajaran sangat perlu dilakukan berulangkali guna mendapatkan desain yang lebih sempurna untuk mengembangkan kemampuan matematis siswa di sekolah dasar.

\section{REFERENSI}

Anderson, L.W. \& David R.K. (2010). Kerangka Landasan untuk Pembelajaran, Pengajaran, dan Asesmen. Yogyakarta: Pustaka Pelajar.

Iskandar, D \& Narsim. (2015). Penelitian Tindakan Kelas dan Publikasinya untuk Meningkatkan Pangkat dan Golongan Guru dan Pedoman Penulisan PTK bagi Mahasiswa. Cilacap: Ihya Media. 
Johnson, E. B. (2008). Contextual Teaching and Learning: Menjadikan Kegiatan Belajar dan Mengajar Mengasyikan dan Bermakna. Bandung: Mizan Learning Center.

Manshur. (2011). Implementasi Pembelajaran Matematika Kontekstual untuk Meningkatkan Kemampuan Pemahaman dan Sikap Siswa terhadap Matematika Siswa Sekolah Dasar. Unpublished Thesis. Bandung: Universitas Pendidikan Indonesia.

Puspita, A.M.I. (2016). Peningkatan Hasil Belajar Siswa Berbantuan Buku Teks Berbasis Kontekstual Untuk Siswa Kelas II Sekolah Dasar. Jurnal Teori, Penelitian, dan Pengembangan, 1(10), 1880-1883.

Puspita, A.M.I. (2018). Pengaruh Penerapan Pendekatan Kontesktual Terhadap Aktivitas dan Hasil Belajar Siswa Di SDN I Campurdarat. Jurnal Penelitian Dewantara, 4(1), 33-45. 
Indriani, Puspita, Ninawati, Handayani \& Agusfianuddin 116 